\title{
HOVERFLIES (DIPTERA, SYRPHIDAE) OF WRANGEL ISLAND (CHUKOTKA AUTONOMOUS OKRUG, RUSSIA)
}

\author{
Anatolij V. Barkalov1 ${ }^{\mathbb{D}}$, Olga A. Khruleva2 ${ }^{\mathbb{D}}$ \\ ${ }^{1}$ Institute of Systematics and Ecology of Animals, Siberian Branch of RAS, Russia \\ e-mail:bark@eco.nsc.ru \\ ${ }^{2}$ A.N. Severtsov Institute of Ecology and Evolution of RAS, Russia \\ e-mail:oa-khruleva@mail.ru
}

Received: 02.09.2020. Revised: 24.12.2020. Accepted: 28.12.2020.

\begin{abstract}
This article continues the series of publications devoted to the inventory of the arthropod fauna of Wrangel Island. It summarises previously unpublished data on about 150 specimens of hoverflies in total (Diptera, Syrphidae) collected by various methods (using individual catching, sweeping, yellow pan traps) from 1972 to 2019 . Features of the fauna composition and the distribution of hoverflies on Wrangel Island are also discussed. A synopsis of the hoverfly fauna of Wrangel Island consists of 16 species, of which nine have been recorded from this territory for the first time, and one species, Platycheirus pullatus, is new for the Palaearctic region. The subfamily Syrphinae (15 species) includes all the genera which are typical for the tundra zone (Eupeodes, Parasyrphus, Platycheirus, Sphaerophoria, Syrphus), whereas the Eristalinae is represented by a single species, Helophilus groenlandicus. The core of the fauna is formed by arctic hoverfly species. About a third consists of widespread species which are common in the northern part of the tundra zone. The vast majority of the species found on Wrangel Island are known from singletons. The most common species is Parasyrphus groenlandicus. In some years, Parasyrphus tarsatus, Eupeodes curtus, Platycheirus aeratus, and P. setitarsis were locally common. On Wrangel Island, the richest hoverfly fauna (12 species) is located in the central, warmest, part, an enclave of a typical tundra subzone. Most of the species found only here (four out of six) were collected in the XXI century, during a warming climate. Despite the clearly incomplete information, the hoverfly fauna on Wrangel Island (where the biota has a long Pleistocene history) is much richer than on most other Arctic islands.
\end{abstract}

Key words: Arctic, fauna, new record, subzonal distribution, tundra zone

\section{Introduction}

Hoverflies, or the syrphids (Diptera, Syrphidae), constitute one of the largest, globally distributed fly families. Within the Palaearctic, its representatives occur from deserts in the south to the arctic tundra in the north. Some species are well adapted to man-made habitats, being a common component of anthropogenic landscapes. The syrphids are rather diverse in the tundra zone, representing an important component of anthophilic insects (Chernov, 1963, 1978a, 1995; Kevan, 1972; Danks, 1981). In the south tundra and foresttundra landscapes of Siberia (i.e. Yamal, Taymyr, Chukotka), local hoverfly faunas contain from 56 (the south tundra of the stow Ary-Mas of the Taymyr State Nature Reserve) to 108 (the foresttundra of the vicinity of Labytnangi) species recorded (Barkalov, 2012, 2015; Barkalov \& Mutin, $2015,2016)$. Yet, only few of these species show their distribution optimum (according to Chernov, 1978b) lying within the limits of the tundra zone. Some 20 species are known from the northern part of Taymyr (subzones of the typical and arctic tundra), with the local fauna comprising up to 17 spe- cies (Barkalov, 2015). Single species of hoverflies are known from most Arctic islands: four species from Novaya Zemlya (Ǿkland, 1928), three from Spitsbergen (Coulson \& Refseth, 2004), five from Ellesmere (Kevan, 1972; Brodo, 2000). To date, seven hoverfly species have been reported from Wrangel Island (Khruleva, 1987; Mutin \& Barkalov, 1999). Further fieldwork on the island has brought new material treated hereinafter.

The present paper summarises all the previously unpublished data on Wrangel Island's syrphids. It continues a series of publications aiming at a complete inventory of arthropods and individual taxa of this entomologically very interesting territory of the Arctic (e.g. Khruleva, 1987, 2007, 2009; Sorokina \& Khruleva, 2012; Khruleva \& Zinchenko, 2017; Grichanov \& Khruleva, 2018; Khruleva \& Stekolshchikov, 2019).

\section{Material and Methods}

In the Arctic, an extraordinary diversity of Wrangel Island's flora and fauna has been stressed in many publications (e.g. Yurtsev, 1987; Stishov, 2004; Khruleva, 2007). This biodiversity is related 
to the landscape and climatic diversity of Wrangel Island's environment, as well as to the lack of covering glaciations in the Pleistocene (Svatkov, 1970; Alfimov, 2007; Vartanyan, 2007). In 1976, the Wrangel Island State Nature Reserve was founded on the island, aiming at an inventory of biological diversity and the monitoring of key components of arctic ecosystems. The majority of Wrangel Island belongs to the subzone of the arctic tundra (Fig.). In inner, warmer areas, there are vegetation enclaves of the subzone of typical tundra (Kholod, 2013). As in other arctic regions, at the turn of the XXI century a climate warming was recorded on Wrangel Island. This manifests itself in increasing summer temperatures, lengthening the frost-free period and periodic autumn-winter thaws, based on data from the meteorological station at the Rogers Bay (www.thermograph.ru, www.pogodaiklimat.ru).

Field collecting of syrphids was undertaken in various years. During three summer seasons of 1966, 1971 and 1972, Diptera were collected by K.B. Gorodkov. In his extensive collection, deposited in the Zoological Institute of RAS (St. Petersburg, Russia; ZIN), there is a series of the syrphids collected in 1972. In 1983-1994, during a survey of the entomofauna of Wrangel Island, hoverflies were collected by O.A. Khruleva using an individual catching. The specimens collected in 1980s were identified by L.V. Zimina (Zoological Museum of the Moscow State University, Moscow, Russia) and partly published (Khruleva, 1987). Small collections of 1992-1993 were identified by the first author (Anatolij V. Barkalov). In the 2000s, the collecting of Diptera (including syrphids) was mainly carried out by quantitative collecting methods. Standard sweepings (no less than four series of 25 strokes each) in model biotopes of several regions of Wrangel Island were undertaken in 2006, 2015 and 2019. Yellow pan traps were used in 2015, 2016, 2018 and 2019, where 3-6 traps with a soap solution were placed in each biotope from one to 20 days (4-6 on average), the removal of insects was carried out every second day. Syrphid specimens collected by sweeping were pinned immediately after the catch, while those collected by traps were preserved in $96 \%$ alcohol and then sorted out and pinned in the lab.

The map (Fig.) shows the main collecting localities of hoverflies for the entire period of research. Districts are given in accordance to their subzone positions. In some Wrangel Island's regions, investigations were undertaken during several field seasons. Particularly well studied are the vicinity of Somnitelnaya Bay (1972, 1986, 1989, 2006, 2015, 2017) and the middle reaches of River Mamomtovaya $(1972,1992,1993,1994,2006,2015,2019)$.

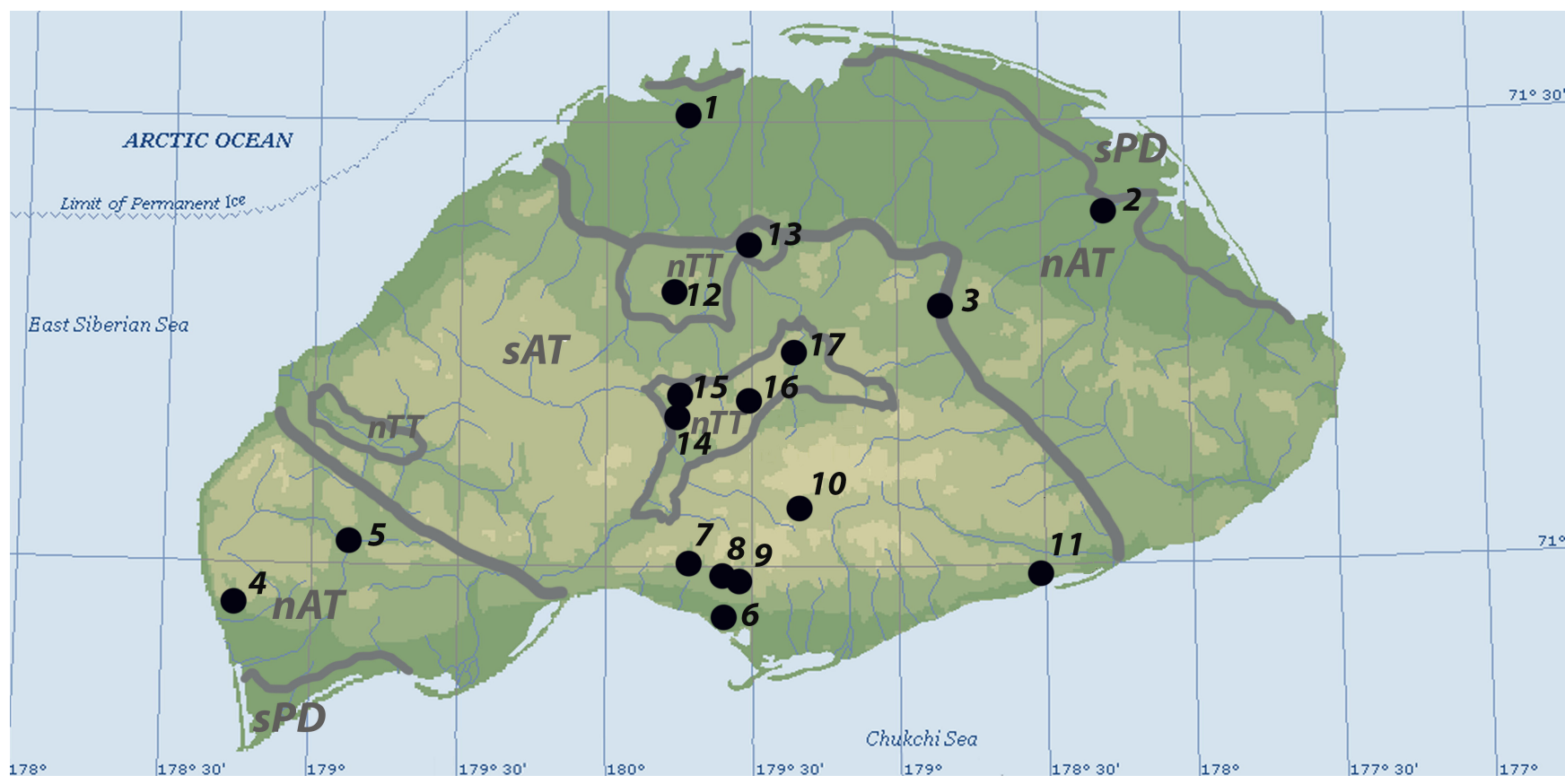

Fig. Map of Wrangel Island with geographic points of Syrphidae flies sampling (black circles). Designations: 1 - lower reaches of River Tundrovaya; 2 - lower reaches of River Naskhok; 3 - upper reaches of River Krasnyi Flag; 4 - Thomas Mt.; 5 - middle reaches of River Neozhidannaya; 6 - Somnitelnaya Bay environs; 7 - Vjuchnyi Pass; 8 - Somnitelnye Mts.; 9 River Somnitelnaya; 10 - upper reaches of River Khischnikov; 11 - Rogers Bay environs; 12 - Tundrovaya Mt.; 13 -middle reaches of River Neizvestnaya; 14 - middle reaches of River Mamontovaya; 15 - brook Veselyi; 16 - spurs of Pervaya Mt.; 17 - upper reaches of River Neizvestnaya. Grey lines indicate boundaries of the zonal differentiation of vegetation according to Kholod (2013): nTT - northern variant of the typical tundra subzone; sAT - southern variant of the Arctic tundra subzone; nAT - northern variant of the Arctic tundra subzone; sPD - southern variant of the zone of polar desert. 
Syrphid specimens from Wrangel Island were mainly collected by O.A. Khruleva. Some specimens were collected by M.V. Berezin (Moscow Zoo, Russia) and the Wrangel Island State Nature Reserve's staff who have been working on the island for several years. In the following text, collectors' names are abbreviated as follows: $\mathrm{KG}-\mathrm{K}$.B. Gorodkov, LV - L.F. Volkova, MB - M.B. Berezin, OKh - O.A. Khruleva, SL - S.S. Lantsov, UB U.V. Babiy. Insect identification was conducted by A.V. Barkalov on the basis of Bartsch et al. (2009) and Mutin \& Barkalov (1999). In difficult cases, flies were compared to vouchers from the reference collection of the Siberian Zoological Museum (SZMN) at the Institute of Systematics and Ecology of Animals SB RAS (Novosibirsk, Russia). The majority of the flies collected in 2006-2019 are deposited in SZMN. The flies collected by K.B. Gorodkov are deposited in ZIN. The data on the hoverflies collected in 1983-1986 and published earlier by Khruleva (1987) are not included in the paragraphs «Material examined» of the present paper, but they have been used for describing the ecology of certain species.

\section{Results}

Subfamily Syrphinae

Eupeodes abiskoensis (Dušek et Láska, 1973)

Material examined. 1) Middle reaches of River Neozhidannaya $\left(71.02^{\circ} \mathrm{N}, 179.15^{\circ} \mathrm{E}\right): 1$, 28.07.2017 (MB); 2) Somnitelnaya Bay environs $\left(70.95^{\circ} \mathrm{N}, 179.63^{\circ} \mathrm{W}\right): 1$ ㅇ, 26.07.2017 (MB).

Distribution. The north of Eurasia, from Scandinavia to Chukotka. This is the first species' record from Wrangel Island.

Ecology. The species was first collected from Wrangel Island in 2017. In the River Neozhidannaya valley, flies were collected from a site with a willow-forb patchy vegetation. On the second site (the left bank of River Somnitelnaya), a single fly was collected from the cobble-loamy dry coastline with a patchy willow-gramineous-forb vegetation and large zoogenic, lemming-related gramineousforb associations.

Eupeodes corollae (Fabricius, 1794)

Reference. Khruleva (1987): 32 (as Syrphus corollae F.).

Distribution. This is a widespread multiregional species occurring from the tundra zone to semideserts, absent from North America.

Ecology. The species is known from Wrangel Island by two specimens collected in 1983 (wet tundra in the middle reaches of River Neizvestnaya) and in 1986 (zonal tundra in the vicinity of Somnitelnaya Bay).

\section{Eupeodes curtus (Hine, 1922)}

Material examined. 1) River Somnitelnaya valley, 4-5 km north of Somnitelnaya Bay: $10^{\lambda} 4$ ㅇ, 05.07.1972 and 25.07.1972 (KG); 2) Somnitelnaya Bay environs $\left(70.95^{\circ} \mathrm{N}, 179.63^{\circ} \mathrm{W}\right)$ : 10, 26.07.2017 (MB); 3) Rogers Bay environs $\left(70.98^{\circ} \mathrm{N}, 178.48^{\circ} \mathrm{W}\right): 14{ }^{\Uparrow} 16$ ㅇ, 06-24.07.1988 (OKh); 4) Middle reaches of River Mamontovaya $\left(71.17^{\circ} \mathrm{N}, 179.77^{\circ} \mathrm{W}\right): 1 \mathrm{O}^{\top}, 15.06 .1992$, from pupa collected on 02.06.1992, (OKh); 5) Middle reaches of River Mamontovaya $\left(71.17^{\circ} \mathrm{N}, 179.77^{\circ} \mathrm{W}\right)$ : 4`6우, 26.06-21.07.2006 (OKh); 6) Brook Veselyi $\left(71.18^{\circ} \mathrm{N}, 179.72^{\circ} \mathrm{W}\right): 1$ ㅇ, 18.07.2019 (OKh); 7) Upper reaches of River Neizvestnaya $\left(71.22^{\circ} \mathrm{N}\right.$, 179.32 $\left.{ }^{\circ} \mathrm{W}\right)$ : $1 \hat{\jmath}$, 05.07.2006 (OKh).

Distribution. This is a trans-Holarctic species occurring predominantly in tundra and forest-tundra landscapes and also in highlands. It is the first species' record from Wrangel Island.

Ecology. The largest series (30 specimens) was collected from Rogers Bay in 1988. Flies occurred in various biotopes on south facing slopes and foothills. In two regions of Wrangel Island, where longstanding collecting was carried out, the majority of flies were collected in a single season only. In the vicinity of Somnitelnaya Bay, the main series was taken from the river valley in its mountain part in 1972. In 2006, near the field station «Srednyaya Mamontovaya», flies were swept off a variety of biotopes. The available data suggest that the species abundance on Wrangel Island is subject to sharp interseasonal fluctuations.

\section{Melangyna sp.}

Reference. Khruleva (1987): 32.

Ecology. The species is known from a single specimen collected from a south facing slope near Somnitelnaya Bay.

Parasyrphus groenlandicus (Nielsen, 1910) Reference. Khruleva (1987): 33 (as Syrphus dryadis Holm.); Mutin \& Barkalov (1999): 394 (as Parasyrphus dryadis Holm.); Barkalov \& Mutin (2018): 497 (as Parasyrphus dryadis (Holmgren, 1869)).

Material examined. 1) Lower reaches of River Tundrovaya $\left(71.48^{\circ} \mathrm{N}, 179.85^{\circ} \mathrm{W}\right)$ : 1 ex., 20.06.1989, from pupa collected on 18.06.1989 $(\mathrm{OKh})$; 2) Thomas Mt. $\left(70.95^{\circ} \mathrm{N}, 178.72^{\circ} \mathrm{E}\right)$ : 1ठ1ㅇ, 10-31.07.2016 (LV); 3) Somnitelnaya Bay 
environs $\left(70.95^{\circ} \mathrm{N}, 179.63^{\circ} \mathrm{W}\right): 1$ \%, 17.06 .2015 , $(\mathrm{OKh}) ; 4)$ Somnitelnaya Bay environs $\left(70.95^{\circ} \mathrm{N}\right.$, $\left.179.63^{\circ} \mathrm{W}\right): 19$, 26.07.2017 (MB); 5) Somnitelnye Mts. $\left(70.98^{\circ} \mathrm{N}, 179.58^{\circ} \mathrm{W}\right): 1$ ex., 26.05.1986, from larva collected on 16.05.1986 pupated on the same date $(\mathrm{OKh})$; 6) River Somnitelnaya valley, 4-9 km north of Somnitelnaya Bay: 79, 05-28.07.1972 (KG); 7) Rogers Bay environs $\left(70.98^{\circ} \mathrm{N}, 178.48^{\circ} \mathrm{W}\right): 2$ ex., 24.07.1988 (OKh); 8) Rogers Bay environs $\left(70.98^{\circ} \mathrm{N}, 178.48^{\circ} \mathrm{W}\right)$ : 19, 11-13.07.2019 (OKh); 9) Tundrovaya Mt. $\left(71.32^{\circ} \mathrm{N}, 179.83^{\circ} \mathrm{W}\right): 1$,, $\left.23.07 .1992(\mathrm{OKh}) ; 10\right)$ Middle reaches of River Mamontovaya $\left(71.17^{\circ} \mathrm{N}\right.$, $\left.179.77^{\circ} \mathrm{W}\right): 19$, 03.07.1993, from pupa collected on 03.06.1993 (OKh); 11) Middle reaches of River Mamontovaya $\left(71.17^{\circ} \mathrm{N}, 179.77^{\circ} \mathrm{W}\right): 1 \delta^{\AA} 3$, 30.06-20.07.2006 (OKh); 12) Middle reaches of River Mamontovaya $\left(71.17^{\circ} \mathrm{N}, 179.77^{\circ} \mathrm{W}\right)$ : $1{ }^{\lambda}$, 02-04.07.2015 (OKh); 13) Middle reaches of River Mamontovaya $\left(71.17^{\circ} \mathrm{N}, 179.77^{\circ} \mathrm{W}\right): 19,17-$ 19.07.2019 (OKh); 14) Brook Veselyi $\left(71.18^{\circ} \mathrm{N}\right.$, 179.72 $\mathrm{W})$ : 1 q , 18.07.2019 (OKh); 15) Upper reaches of Neizvestnaya River $\left(71.22^{\circ} \mathrm{N}\right.$, 179.32 $\left.{ }^{\circ} \mathrm{W}\right): 19$, 04-15.07.2015 (OKh); 16) Upper reaches of River Neizvestnaya $\left(71.22^{\circ} \mathrm{N}\right.$, 179.32 $\left.{ }^{\circ} \mathrm{W}\right): 1$ \% , 20-22.07.2019 (OKh).

Distribution. This is a trans-Holarctic species known from Scandinavia to western North Ameri$\mathrm{ca}$, in the tundra and forest-tundra zones.

Ecology. This is the most common hoverfly species of Wrangel Island collected by various methods (sweeping, yellow pan traps, hand collecting) in a wide range of climatic conditions: from the coastal plains to the warmest inland regions of Wrangel Island. Flies inhabit a variety of moderately humid habitats, including zonal plant communities. The species was recorded in various years but almost always in small quantities. Series of several specimens were collected from Somnitelnaya Bay in 1972 (from foothills and mountains, some occurred on plants of Dryas integrifolia Vahl.) and in 1986 (Khruleva, 1987). In the second season, flies were collected from south facing slopes and foothills (five specimens), as well as from the plain (ten specimens, of which eight flies in a single sample were taken from the zonal tundra). The overwintering stage of this species is larvae that have completed their development. This is indicated by collecting a larva that pupated at the beginning of the season (mid-May) or, in some years, the pupas from which flies hatched in the early/mid-June. In some warm seasons (1986, 2015), the first flies appeared in mid-June. In the remaining seasons flies occurred from late June to late July.

\section{Parasyrphus tarsatus (Zetterstedt, 1838)}

Reference. Khruleva (1987): 33 (as Syrphus tarsatus Zett.).

Material examined. 1) Upper reaches of River Krasnyi Flag $\left(71.27^{\circ} \mathrm{N}, 179.83^{\circ} \mathrm{W}\right)$ : 1 q, 16-27.07.2011 (SL); 2) River Somnitelnaya valley, $1-5 \mathrm{~km}$ north of Somnitelnaya Bay: $5 \jmath^{\lambda}$ ㅇ, 07-25.07.1972 (KG); 3) Rogers Bay environs $\left(70.98^{\circ} \mathrm{N}, 178.5^{\circ} \mathrm{W}\right): 22$ ex., 16.06-01.08.1988 $(\mathrm{OKh})$; 4) Middle reaches of River Mamontovaya $\left(71.17^{\circ} \mathrm{N}, 179.77^{\circ} \mathrm{W}\right)$ : $1 \delta^{\lambda}, 08.07 .2006(\mathrm{OKh})$.

Distribution. This is a trans-Holarctic species known from Scandinavia east to Greenland, common in the zonal and alpine tundra.

Ecology. This species was collected in the vicinity of Somnitelnaya Bay in 1972 and 1986. In both seasons the flies were observed in the plain as well as in the mountainous part: i.e. in the river valley and on south facing slopes. Over all field seasons, the largest series (22 specimens) was taken from Rogers Bay in 1988, with the flies occurring in the sandy-pebble floodplain of the river valley, dry south facing slopes and foothills with a patchy forb-moss-sedge vegetation. Considering that in other seasons only single specimens of $P$. tarsatus were recorded, it is reasonable to assume that its population on Wrangel Island is subject to sharp interseasonal fluctuations.

\section{Platycheirus (Platycheirus) aeratus Coquillet, 1900}

Reference. Khruleva (1987): 32 (as Platycheirus angustitarsis Kan.); Mutin \& Barkalov (1999): 372.

Material examined. 1) River Somnitelnaya valley, $4 \mathrm{~km}$ north of Somnitelnaya Bay: $1 \hat{\sigma}^{\text {त }}$, 23.07.1972 (KG); 2) Somnitelnaya Bay environs, Bazovaya lagoon $\left(70.95^{\circ} \mathrm{N}, 179.52^{\circ} \mathrm{W}\right): 1 \delta^{\lambda}$, 19.07.2015 (OKh); 3) Middle reaches of River Ma-

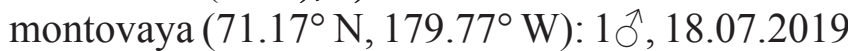
$(\mathrm{OKh})$; 4) Spurs of Pervaya Mt., «Bobovaya range» $\left(71.15^{\circ} \mathrm{N}, 179.45^{\circ} \mathrm{W}\right): 4$ ex., 31.07 .1989 (OKh); 5) Middle reaches of River Neizvestnaya $\left(71.33^{\circ} \mathrm{N}, 179.47^{\circ} \mathrm{W}\right)$ : $8 \hat{\jmath}, 29.07 .1989(\mathrm{OKh})$.

Distribution. This is a trans-Holarctic species occurring from Scandinavia east to the northern Canada, predominantly in tundra landscapes and also highlands.

Ecology. Both specimens from the Somnitelnaya Bay (see above) were collected from moist sites: in 1972, swamp in the river valley, and in 2015 , by sweeping over grasses and cottongrass 
(Eriophorum sp.) along a small lake shore. Contrary to that, in the centre of Wrangel Island the species occurred in dry habitats: the rubble hill slopes with a sparse forb-lichen vegetation (in 1989) and zoogenic meadow around an Arctic fox (Vulpes (Alopex) lagopus Linnaeus, 1758) hole, with a forb-grass-wormwood vegetation (in 2019).

Platycheirus (Pachysphyria) ? ambiguus (Fallén, 1817)

Material examined. 1) Middle reaches of River Mamontovaya $\left(71.17^{\circ} \mathrm{N}, 179.77^{\circ} \mathrm{W}\right): 1{ }^{\lambda}$, 05.07.1992 (OKh).

Distribution. This is a widespread species in the temperate and southern Palaearctic and the Oriental region. It is the first species' record from Wrangel Island.

Ecology. One specimen was found in the centre of Wrangel Island: a ridge slope with a forbleguminous vegetation.

Note. We have put this species with a question mark, since the identification of this species is in doubt; however, the only specimen is lost.

Platycheirus (Platycheirus) chilosia (Curran, 1922)

Material examined. 1) Near Viyuchnyi Pass, northeast of Somnitelnaya Bay: 2O, 17.07.1972 and 21.07.1972 (KG);2) 2-5 km north of Somnitelnaya Bay: 46ㅇ, 05-19.07.1972 (KG); 3) Middle reaches of River Neizvestnaya: 2今, 29.06.1989 and 01.07.1989 (OKh); 4) Middle reaches of River Mamontovaya $\left(71.17^{\circ} \mathrm{N}, 179.77^{\circ} \mathrm{W}\right)$ : $1{ }^{\lambda}$, 05.07.1992 (OKh); 5) Middle reaches of River Mamontovaya $\left(71.17^{\circ} \mathrm{N}, 179.77^{\circ} \mathrm{W}\right): 1 \delta^{\Uparrow} 2$, 26.06.2006, 08-09.07.2006 (OKh).

Distribution. This is a trans-Holarctic species occurring from northern Scandinavia to northern Canada, predominantly in tundra landscapes and also highlands. It is the first species' record from Wrangel Island.

Ecology. The largest series of this species was collected in 1972 from the plains and foothills near Somnitelnaya Bay. Data labels of some specimens specify that they were collected from the spotted tundra. In the following seasons, the species was not found in this part of Wrangel Island. In 2006, flies were collected by sweeping over the herb-willow-moss and forb-Dryas vegetation.

Platycheirus (Platycheirus) pullatus Vockeroth, 1990

Material examined. 1) Viyuchnyi Pass, northwest of Somnitelnaya Bay: 19, 21.07.1972 (KG); 2) Upper reaches of River Khischnikov, $7 \mathrm{~km}$ south of Sovetskaya Mt.: 1ठ, 11.07.1972(KG).
Distribution. This is a new species record for the fauna of Russia and the Palaearctic. Previously the species was known from the territory of North America (Canada: Northwest Territories, Yukon, Alberta).

Ecology. Both specimens were collected in the same season from the mountains in the south part of Wrangel Island, on flowers of Dryas sp.

Platycheirus (Platycheirus) setitarsis Vockeroth, 1986

Reference. Mutin \& Barkalov (1999): 365.

Material examined. 1) Middle reaches of River Neozhidannaya $\left(71.02^{\circ} \mathrm{N}, 179.15^{\circ} \mathrm{E}\right)$ : $4{ }^{\lambda}, 12-16.07 .2016(\mathrm{LV})$; 2) Middle reaches of River Neozhidannaya $\left(71.02^{\circ} \mathrm{N}, 179.15^{\circ} \mathrm{E}\right): 19$, 08.07.2019 (OKh); 3) Tundrovaya Mt. $\left(71.32^{\circ} \mathrm{N}\right.$, $\left.179.83^{\circ} \mathrm{W}\right): 1$ ㅇ, 30.06-06.07.2018 (UB); 4) Middle reaches of River Mamontovaya $\left(71.17^{\circ} \mathrm{N}\right.$, $\left.179.77^{\circ} \mathrm{W}\right)$ : $1 \mathrm{O}^{\lambda}, 05.07 .1992$ (OKh); 5) Middle reaches of River Mamontovaya $\left(71.17^{\circ} \mathrm{N}\right.$, $\left.\left.179.77^{\circ} \mathrm{W}\right): 20^{\Uparrow} 19,08-09.07 .2006(\mathrm{OKh}) ; 6\right)$ Upper reaches of River Neizvestnaya $\left(71.22^{\circ} \mathrm{N}\right.$, 179.32 $\left.{ }^{\circ} \mathrm{W}\right): 1$ \% , 06.07.2006 (OKh).

Distribution. It inhabits the Siberian tundra, from Taymyr to Chukotka, and North America.

Ecology. Flies were collected by sweeping and yellow pan traps in the regions with various landscape-climatic conditions, occurring in wet sites along river valleys and creeks with a herbwillow-moss vegetation, as well as in moderately wet slopes with a moss-willow-herb vegetation.

\section{Platycheirus sp. 1}

Material examined. 1) Middle reaches of River Mamontovaya $\left(71.17^{\circ} \mathrm{N}, 179.77^{\circ} \mathrm{W}\right): 1$, 26.06.2006 (OKh).

Ecology. The fly was collected from the central part of Wrangel Island, from a dry ridge with a forbs-Dryas vegetation.

Note. Due to the poor quality of its condition, the specimen was impossible to identify. In its size and colouration, the specimen does not conform to any of the aforementioned Platycheirus species.

\section{Sphaerophoria (Sphaerophoria) philantha}

(Meigen, 1822)

Material examined. 1) Middle reaches of River Mamontovaya $\left(71.17^{\circ} \mathrm{N}, 179.77^{\circ} \mathrm{W}\right)$ : 1ठ2, 18.07.2019, (OKh); 2) Upper reaches of River Neizvestnaya $\left(71.22^{\circ} \mathrm{N}, 179.22^{\circ} \mathrm{W}\right): 1$, 29.07.2015 (OKh).

Distribution. This is a polyzonal, trans-Holarctic species. It is the first species' record from Wrangel Island. 
Ecology. The species was collected by sweeping from the warmest central part of Wrangel Island: a dry river brow with a tundra-steppe forbsedge vegetation (in 2015) and zoogenic meadow around an Arctic fox hole, with a forb-grass-wormwood vegetation (in 2019).

Syrphus attenuatus Hine, 1922

Material examined. 1) Middle reaches of River Mamontovaya $\left(71.17^{\circ} \mathrm{N}, 179.77^{\circ} \mathrm{W}\right): 3$, 21.07.2006 (OKh).

Distribution. This is a trans-Holarctic polyzonal species occurring from Scandinavia east to northern Canada and south through the mountains as far as Colorado. It is the first species' record from Wrangel Island.

Ecology. All specimens were collected in one season by sweeping from a moderately wet ridge with a herb-willow-moss vegetation and a dry willow-forb-grass meadow.

Syrphus torvus Osten-Sacken, 1875

Reference. Khruleva (1987): 33.

Distribution. This is a multi-regional species, occurring from the tundra to the subtropical forests of the Holarctic and Oriental regions.

Ecology. The only specimen of this species was collected from the climatically most severe, north-eastern part of Wrangel Island: the zonal tundra in the lower reaches of River Naskhok.

Subfamily Eristalinae

Helophilus groenlandicus (Fabricius, 1780)

Material examined. 1) Middle reaches of River Mamontovaya $\left(71.17^{\circ} \mathrm{N}, 179.77^{\circ} \mathrm{W}\right): 1$, 13.08.2006 (OKh).

Distribution. This is a trans-Holarctic species known from northern Europe, Siberia to the north of North America. It is the first species' record from Wrangel Island.

Ecology. The only specimen of this species was collected from the central part of Wrangel Island, in a zoogenic meadow around an Arctic fox hole, with a forb-grass-wormwood vegetation. Despite the collecting of Diptera being undertaken in this biotope many times from the late June to mid-August, the fly was found in the latest sample taken from that site.

The present paper considers 16 hoverfly species, of which nine have been recorded from Wrangel Island for the first time. Parasyrphus groenlandicus, $P$. tarsatus, Platycheirus aeratus and $P$. setitarsis were previously reported from Wrangel Island (Khruleva, 1987; Mutin \& Barkalov, 1999). Three species, Eupeodes corollae, Syrphus torvus and Melangyna sp., are known from Wrangel Island only from the material resulted from the 1983-1986 field seasons (Khruleva, 1987). Based on all the available data, the hoverfly fauna of Wrangel Island accounts for 16 species, of which 15 belong to Syrphinae.

The majority of hoverfly species collected from Wrangel Island are represented by singletons, many were found in one season only (Table). Parasyrphus groenlandicus was the only species recorded regularly over many seasons. In some seasons, rather large series (five or more specimens) were collected for the following species: Eupeodes curtus (in 1972, 1988, 2006), Parasyrphus tarsatus (in 1972, 1986, 1988), Platycheirus aeratus (in 1983, 1989), P. chilosia (in 1972) and P. setitarsis (in 2006, 2016). It is characteristic that the first two species were especially abundant around Rogers Bay in 1988, when a high abundance of the aphid Aphis polaris Stekolshchikov \& Khruleva, 2014 was observed too (Khruleva, 2009: as Aphis sp.). This aphis species demonstrated pronounced fluctuations of its abundance between seasons and was especially numerous in the late 1980 s (Stekolshchikov \& Khruleva, 2014; Khruleva \& Stekolshchikov, 2019).

The highest species diversity is observed in the central, warmest part of Wrangel Island (the subzone of typical tundra) with 12 species, of which six were found only here. The most common elements of this fauna are Eupeodes curtus, Parasyrphus groenlandicus, Platycheirus aeratus and $P$. chilosia. The best studied local fauna of the middle reaches of River Mamontovaya consists of 11 species, of which about a half was collected from this region merely once. In 2006 alone, there were quite a few syrphids here (27 specimens belonging to eight species; in other seasons only singletons were collected). Of the nine species collected from the south variant of the subzone of the arctic tundra, only three species could be called fairly common: Eupeodes curtus, Parasyrphus groenlandicus and P. tarsatus. The best-studied local fauna in the vicinity of the Somnitelnaya Bay includes all these nine species. In the northern variant of the arctic tundra subzone, a single species has been recorded (Table), Platycheirus setitarsis, collected in the 2010s in several specimens. 
Table. Distribution of Syrphidae in various subzones of Wrangel Island

\begin{tabular}{|c|c|c|c|c|c|c|}
\hline \multirow{3}{*}{ Taxa } & \multicolumn{4}{|c|}{ Arctic tundra subzone } & \multirow{2}{*}{\multicolumn{2}{|c|}{$\begin{array}{l}\text { Northern variant of typical tundra subzone } \\
\text { (central part of Wrangel Island) }\end{array}$}} \\
\hline & \multicolumn{2}{|c|}{ Northern variant } & \multicolumn{2}{|c|}{ Southern variant } & & \\
\hline & 1970-1990s & 2000-2010s & 1970-1990s & $2000-2010 \mathrm{~s}$ & 1970-1990s & 2000-2010s \\
\hline Eupeodes abiskoensis* & - & + & - & + & - & - \\
\hline Eupeodes corollae & - & - & + & - & + & - \\
\hline Eupeodes curtus & - & - & ++ & + & + & ++ \\
\hline \begin{tabular}{|l|} 
Parasyrphus groenlandicus \\
\end{tabular} & + & + & ++ & + & + & + \\
\hline Parasyrphus tarsatus & - & - & ++ & + & - & + \\
\hline Melangyna sp.* & - & - & + & - & - & - \\
\hline Platycheirus aeratus & - & - & + & + & ++ & + \\
\hline Platycheirus? ambiguus* & - & - & - & - & + & - \\
\hline Platycheirus chilosia & - & - & + & - & + & + \\
\hline Platycheirus pullatus* & - & - & + & - & - & - \\
\hline Platycheirus setitarsis & - & + & - & - & + & ++ \\
\hline Platycheirus sp. $1^{*}$ & - & - & - & - & - & + \\
\hline Sphaerophoria philantha & - & - & - & - & - & + \\
\hline Syrphus attenatus* & - & - & - & - & - & + \\
\hline Syrphus torvus* & + & - & - & - & - & - \\
\hline Helophilus groenlandicus* & - & - & - & - & & + \\
\hline Total species & \multicolumn{2}{|c|}{4} & \multicolumn{2}{|c|}{9} & \multicolumn{2}{|c|}{12} \\
\hline
\end{tabular}

Note: $\langle+\rangle-$ the species was collected in single specimens, «++》 - five or more specimens were collected in some years; $\left\langle{ }^{*}\right\rangle-$ species were collected only in one of the seasons.

\section{Discussion}

The hoverfly fauna of Wrangel Island is dominated by species of the subfamily Syrphinae. This subfamily is represented by genera, which are most common in the northern part of the tundra zone (the subzones of arctic and typical tundra): Eupeodes, Parasyrphus, Platycheirus and Syrphus (Chernov, 1963, 1978b; Barkalov, 2015). The Syrphinae species diversity is comparable to that of the northern Taymyr (Barkalov, 2015), and it significantly exceeds those of other arctic island territories. For instance, the syrphid fauna of Victoria Island (Canadian Arctic Archipelago) consists of nine species (Vockeroth, 1992), whereas no more than 2-4 species of this subfamily are known from the remaining arctic islands (Ǿkland, 1928; Kevan, 1972; Brodo, 2000; Coulson \& Refseth, 2004). On the contrary, the subfamily Eristalinae is almost completely absent from Wrangel Island (a single fly of the genus Helophilus was collected), whereas it accounts for over a quarter of the Taymyr hoverfly fauna, i.e. six of the 21 recorded species (Barkalov, 2015).

On Wrangel Island, hoverflies with a circumpolar range predominate (almost half of them also occur in highlands of the southern mountain systems), as well as arcto-boreal and arcto-temperate Holarctic species being typical components of the hoverfly fauna in the tundra zone. About a third of the studied fauna consists of polyzonal species (Eupeodes corollae, Syrphus attenuatus, Platycheirus ? ambiguus, Sphaerophoria philantha) that usually occur in the tundra zone near its southern borders.

Paucity of hoverflies in collections from Wrangel Island may be partly due to the lack of special studies of this group carried out there. Based on the available literature, in most other parts of the northern tundra zone Syrphidae are also known from singular records. The available data from the Siberian sector of the Arctic (Chernov, 1963, 1978a,b; Barkalov, 2015) also indicate the occasional encounters of most hoverfly species in the north of the tundra zone, especially in the subzone of the arctic tundra. In the northern part of Taymyr, abundant material of hoverflies (about 400 specimens of 15 species) was collected once, in the vicinity of Dikson (River Lemberova) in 2012 (Barkalov, 2015). In this case, the main collecting method producing the bulk of specimens was individual collecting by an aerial net over the flowering vegetation. Yet, specimens of all the recorded species were also caught by yellow pan traps.

Of the six most regular components of the hoverfly fauna in the northern Taymyr (Barka- 
lov, 2015), four species were collected from Wrangel Island: Parasyrphus groenlandicus, $P$. tarsatus, Platycheirus setitarsis, and Helophilus groenlandicus. Several other species reported from Wrangel Island, Eupeodes corollae, Platycheirus aeratus, $P$. ? ambiguus, $P$. chilosia, Sphaerophoria philantha, and Syrphus attenatus, are limited to its southern regions in Taymyr, representing the southern tundra, foresttundra and north taiga sparse forest (Barkalov, 2015). This determines a higher similarity in hoverfly species composition of Wrangel Island to that of the southern rather than the northern Taymyr (11 and eight species correspondingly). It is safe to assume that small numbers of most registered species from Wrangel Island are due to their occurrence there beyond their climatic optimum. This is also confirmed by the peculiarities of the hoverfly distribution across the zonal gradient of Wrangel Island (Table).

Overall, during the period of climate warming (since early 2000s) five conditionally «new» hoverfly species have been recorded, with four of them being found in the warmest, central part of Wrangel Island (Table). This observation is in good agreement with the available data on other insect groups, of which the majority of similarly «new» species are also confined to the central part of Wrangel Island (Khruleva \& Zinchenko, 2017; Grichanov \& Khruleva, 2018; Khruleva \& Stekolshchikov, 2019). Thus, it is unlikely that all of them have recently penetrated the Wrangel Island's ecosystems. The activity of several such species, including flies of the families Chloropidae, Dolichopodidae and Calliphoridae, had markedly increased by 2015, whereas three of the five «new» hoverfly species were collected merely once in 2006, at the beginning of climatic changes. Some increase in abundance in recent years can only be suggested for Sphaerophoria philantha (the species was registered in 2015 and 2019) and Platycheirus setitarsis (ten out of 11 specimens were collected in XXI century). Thus, it seems that at the present stage of climatic alterations there is no marked increase in activity of the majority of hoverfly species in the ecosystems of Wrangel Island.

\section{Conclusions}

The currently available data indicate a high species richness of the studied hoverfly fauna in comparison with other Arctic islands. It dif- fers not only in the presence of the most common Arctic hoverflies, but also in a number of widespread multizonal species, usually found only on the southern borders of the tundra zone. These features are undoubtedly associated not only with the landscape and climatic diversity of this relatively small island, but also with its long Pleistocene history. Taking into account the sporadic occurrence of most species, it can be assumed that upon further study, the fauna of hoverflies on Wrangel Island will be supplemented with new species.

\section{Acknowledgements}

We are grateful to A.R. Gruzdev (Director of the Wrangel Island State Nature Reserve) for the organisation of fieldworks and to the staff of the Wrangel Island State Nature Reserve who took part in collecting the studied material: I.P. Oleinikov, L.F. Volkova (Simon), U.V. Babiy, S.S. Lantsov. We also thank M.V. Berezin (Moscow Zoo, Russia), whose collections were used in the present paper, the curators of the ZIN's Diptera collection, O.G. Ovtchinnikova and G.M. Suleimanova (Zoological Institute of RAS, Russia), allowed us to study the material by K.B. Gorodkov. We are sincerely grateful to Dmitry Logunov (The Manchester Museum, the University of Manchester, United Kingdom) for translating our article into English. The work of A.V. Barkalov was supported by the RFFI grant №20-04-00027-a, and partly the Federal Fundamental Scientific Research Programme for 2013-2020 (AAAA-A16-116121410121-7). The work of O.A. Khruleva was undertaken with the support of the RFFI grant №20-04-00165.

\section{References}

Alfimov A.A. 2007. Temperature status of interior parts of Wrangel Island. In: A.R. Gruzdev (Ed.) Nature of Wrangel Island. Recent Studies. St. Petersburg: Asterion. P. 237-253. [In Russian]

Barkalov A.V. 2012. Comparative analysis of Diptera faunas of hypoarctic of Taymyr Peninsula and high mountains of Altai. Caucasian Entomological Bulletin 8(2): 349-352. [In Russian]

Barkalov A.V. 2015. Hover-flies (Diptera, Syrphidae) of the Taymyr Peninsular. Part 1. Euroasian Entomological Journal 14(1): 54-62. [In Russian]

Barkalov A.V., Mutin V.A. 2015. Hover-flies (Diptera, Syrphidae) of the Anadyr River lower reach territory, Chukotka Autonomnyi Okrug of Russia. Euroasian Entomological Journal 14(4): 346-359. [In Russian]

Barkalov A.V., Mutin V.A. 2016. Hover-flies (Diptera, Syrphidae) of two local faunas of the Yamal Peninsula. Euroasian Entomological Journal 15(3): 239249. [In Russian] 
Barkalov A.V., Mutin V.A. 2018. Checklist of the hoverflies (Diptera, Syrphidae) of Russia. Euroasian Entomological Journal 17(6): 466-510. [In Russian]

Bartsch H., Binkiewicz E., Rådén A., Nasibov E. 2009. Blomflugor: Syrphinae. In: Nationalnyckeln till Sveriges flora och flora. DH53a. Uppsala: Artdatabanken, SLU. 406 p.

Brodo F. 2000. The insects, mites, and spiders of Hot Weather Creek, Ellesmere Island, Nunavut. Bulletin of Geological Survey of Canada 529: 145-173. DOI: 10.4095/211956

Chernov Yu.I. 1963. Materials on the fauna of syrphids (Diptera, Syrphidae) of the tundra zone. Uchenye Zapiski of the Moscow Region Pedagogical Institute 126(6): 101-107. [In Russian]

Chernov Yu.I. 1978a. Antophilic insects in the subzone of typical tundras of Western Taymyr and their role in pollination of plants. In: Structure and function of biogeocenoses of the Taymyr tundra. Leningrad: Nauka. P. 264-290. [In Russian]

Chernov Yu.I. 1978b. The structure of the animal population of the Subarctic. Moscow: Nauka. 167 p. [In Russian]

Chernov Yu.I. 1995. The order Diptera (Insecta) in the Arctic fauna. Zoologicheskii Zhurnal 74(5): 68-83. [In Russian]

Coulson S.J., Refseth D. 2004. The terrestrial and freshwater invertebrate fauna of Svalbard. In: P. Prestrud, H. Strøm, H.V. Goldman (Eds.): A catalog of the terrestrial and marine animals of Svalbard. Tromsø: Norwegian Polar Institute. P. 57-122.

Danks H.V. 1981. Arctic arthropods, a review of systematics and ecology with particular reference to the North American fauna. Ottawa: Entomological Society of Canada. 605 p.

Grichanov I.Ya., Khruleva O.A. 2018. Fauna and ecology of Dolichopodidae (Diptera) from Wrangel Island Nature Reserve (Chukotka, Russia). Nature Conservation Research 3(3): 37-45. DOI: 10.24189/ncr.2018.023

Kevan P.G. 1972. Insect pollination of High Arctic Flowers. Journal of Ecology 60(3): 831-847. DOI: $10.2307 / 2258569$

Kholod S.S. 2013. Zonation in the plant cover on the Wrangel Island: syntaxonomical approach. Vegetation of Russia 23: 89-121. [In Russian]

Khruleva O.A. 1987. Invertebrates. In: V.E. Sokolov, T.M. Korneeva (Eds.): Flora and Fauna of Reserves of the USSR: Fauna of the Wrangel Island Reserve. Moscow. P. 6-36. [In Russian]

Khruleva O.A. 2007. Peculiarity of terrestrial Arthropod fauna in view of Environment of the Wrangel Island. In: A.R. Gruzdev (Ed.): Nature of Wrangel Island. Recent Studies. St. Petersburg: Asterion. P. 136-175. [In Russian]
Khruleva O.A. 2009. Arthropod assemblages of the Wrangel Island in a context of recent and Pleistocene tundra-steppe insect faunas of the northeastern Asia. In: A.B. Babenko, N.V. Matveyeva, O.L. Makarova, S.I. Golovatch (Eds.): Species and Communities in Extreme Environments. Moscow-Sofia: KMK Scientific Press Ltd. and PENSOFT. P. 124167. [In Russian]

Khruleva O.A., Stekolshchikov A.V. 2019. Additions to the aphid fauna of Wrangel Island due to climate change with redescription of the oviparous female of Pterocomma groenlandicum Hille Ris Lambers, 1952 (Hemiptera, Aphidoidea). Zootaxa 4615(3): 511-528. DOI: 10.11646/zootaxa.4615.3.6

Khruleva O.A., Zinchenko V.K. 2017. Blowflies (Diptera, Calliphoridae) of the Wrangel Island, Chukotka, Russia. Euroasian Entomological Journal 16(4): 388 394. DOI: 10.15298/euroasentj.16.4.13 [In Russian]

Mutin V.A., Barkalov A.V. 1999. Family Syrphidae hover-flies. In: P.A. Ler (Ed.): Key to insects of the Far East. Vol. 6, part 1. Vladivostok: Dalnauka. P. 342-500. [In Russian]

Ǿkland F. 1928. Land- und süsswasserfauna von Nowaja Semlja (Report of the Scientific Results of the Norvegian Expedition to Novaya Zemlya, 1921. Vol. 2). Oslo: (Kristiania) A.W. Brǿggers Boktrykikeri A.S. 125 p.

Sorokina V.S., Khruleva O.A. 2012. Details of species composition and distribution of house-flies (Diptera, Muscidae) of the Wrangel Island, Russia. Euroasian Entomological Journal 11(6): 553-564. [In Russian]

Stekolshchikov A.V., Khruleva O.A. 2014. A contribution to the aphid fauna (Hemiptera: Aphididae) of Wrangel Island. Zootaxa 3887(3): 298-320. DOI: 10.11646/zootaxa.3887.3.2

Stishov M.S. 2004. Wrangel Island as a natural standard and a natural anomaly. Yoshkar-Ola: Mari Polygraph Complex. 596 p. [In Russian]

Svatkov N.M. 1970. Wrangel Island. In: I.P. Gerasimov (Ed.): The Soviet Arctic. Moscow: Nauka. P. 453-481. [In Russian]

Yurtsev B.A. 1987. The effect of historical factors on the adaptation of plants to extreme environmental conditions of the arctic tundra subzone (Wrangel Island flora taken in example). Botanicheskii Zhurnal 72(11): 1436-1447. [In Russian]

Vartanyan S. L. 2007. Wrangel Island at the end of the Quaternary: geology and paleogeography. St. Petersburg: Publishing House of Ivan Limbach. 144 p.

Vockeroth J.R. 1992. The Flower Flies of the Subfamily Syrphinae of Canada, Alaska, and Greenland. Diptera: Syrphidae. In: The Insects and Arachnids of Canada. Vol. 18. Ottawa: Agriculture Canada. 456 p. 


\title{
МУХИ-ЖУРЧАЛКИ (DIPTЕRA, SYRPHIDAЕ) ОСТРОВА ВРАНГЕЛЯ (ЧУКОТСКИЙ АВТОНОМНЫЙ ОКРУГ, РОССИЯ)
}

\author{
А. В. Баркалов ${ }^{1}\left(\mathbb{D}\right.$, О. А. Хрулева ${ }^{2}$ \\ ${ }^{1}$ Институт систематики и экологии животных СО РАН, Россия \\ e-mail:bark@eco.nsc.ru \\ ${ }^{2}$ Институт проблем экологии и эволюичии имени А.Н. Северияова, Россия \\ e-mail:oa-khruleva@mail.ru
}

\begin{abstract}
Данная статья продолжает серию публикаций, посвященных инвентаризации фауны членистоногих острова Врангеля. В ней обобщены ранее не публиковавшиеся данные по журчалкам (Diptera, Syrphidae), собранным различными методами (ручной сбор, кошение, желтые тарелки - всего около 150 экз.) в период с 1972 по 2019 гг., а также рассматриваются особенности состава фауны и распределения видов на территории острова. В настоящее время с острова Врангеля известно 16 видов, из которых девять впервые указываются для этой территории, а Platycheirus pullatus - для фауны Палеарктики. Подсемейство Syrphinae (15 видов) содержит все наиболее характерные для тундровой зоны роды (Eupeodes, Parasyrphus, Platycheirus, Sphaerophoria, Syrphus), тогда как Eristalinae представлено всего одним видом (Helophilus groenlandicus). Основу фауны составляют арктические виды журчалок, примерно треть приходится на широкоареальные виды, обычно не встречающиеся в северной части тундровой зоны. Подавляющее большинство видов известно на острове Врангеля по единичным экземплярам. К числу наиболее обычных видов относится Parasyrphus groenlandicus. В отдельные годы локально обычны Parasyrphus tarsatus, Eupeodes curtus, Platycheirus aeratus и P. setitarsis. Наиболее богата (12 видов) фауна центральной, самой теплой части (анклав подзоны типичных тундр). Большинство видов, известных только из этой части острова Врангеля (четыре из шести), собраны в XXI в. (в период потепления климата). Несмотря на явно неполную изученность, фауна журчалок острова Врангеля существенно богаче фаун большинства других арктических островов.
\end{abstract}

Ключевые слова: Арктика, новое указание, подзональное распределение, тундровая зона, фауна 